\title{
CASE STUDY: AIRCRAFT PASSENGER'S MOTIVE THAT POTENTIALLY THREATEN THE FLIGHT SAFETY AND SECURITY
}

\author{
Erwansyah Sjarief $^{1}$, Arini Syahradzi ${ }^{2}$ \\ 1. Universitas Marsekal Dirgantara, 2. Universitas Indonesia \\ Corresponding Author : erwansyahsjarief4558@gmail.com
}

\begin{abstract}
To date, human error in the world of flight is more associated to flight personnel, both aircrew and ground crew. However, in recent years, aircraft passengers could also be the cause of the plane crash or accident. There are various motives, such as dangerous actions taken by passengers, that might lead to the occurrence of aircraft accidents. In Indonesia, the same situation occurs, where there are also many passenger behavior that potentially threaten the aviation safety and security, but not to the occurrence of aircraft accidents. The dangerous actions carried out by passengers is not based on criminal or terror motives, but it is still required to watch out for.

This research is a descriptive qualitative research with case study approach. Data were collected from various sources such as from the law / acts and news in the mass media. To test the validity of the data and to find the objective truth, the researcher conducted a triangulation of the data source.This study concludes that the dangerous action carried out by passengers which could threaten the flight safety and security is due to their limited knowledge and understanding of the rules of legislation.
\end{abstract}

Keywords: motives, passengers, flight safety and security

\section{Introduction}

Flight safety and security is the heart of all flight operation process. One of the cause of the aircraft accident is neglecting the flight safety and security. Flight safety and security are absolute, and could not be compromised. Humans will not be able to $100 \%$ eliminate accidents. What humans can do is minimize accidents, one of them by adhering to the rules and procedures of aviation safety and security.

The definition of aviation safety as stipulated in article 1, paragraph 48 of Act No. 1 Year 2009 on Aviation is the fulfillment of safety requirements when utilizing airspace, aircraft, airport, air cargo, flight navigation, as well as supporting facilities and other public facilities. Meanwhile, the definition of aviation security as set forth in article 49, is how to protect flights from unlawful acts in an integrated way by utilizing human resources, facilities and procedures. (Kementerian Hukum dan Hak Asasi Manusia Republik Indonesia, 2009) 
Many people assumes that the flight safety and security is only the responsibility of certain parties, such as government or airline operators. In fact, it is the responsibility of all parties, including those who are not using aviation services, in the sense of not taking any action that could compromise the safety and security of aviation. As an example, the public's lack of understanding of aviation safety and security in Indonesia is using highpowered radio frequencies illegally. This action will obviously interfere with air navigation, such as interrupting the conversation between the pilot and the ATC officers. Anyone is prohibited from using aviation radio frequencies, other than for aviation purposes, either directly or indirectly which may adversely affect flight safety as stipulated in article 306 (Kementerian Hukum dan Hak Asasi Manusia Republik Indonesia, 2009). Article 431 paragraph 1 describes that the perpetrators who use aviation radio frequencies, either directly or indirectly that may interfere with flight safety, shall be subject to a maximum imprisonment of five years and a maximum fine of one hundred million rupiah. Point 2 of the article stated that if it is causing death, will be subject to a maximum of fifteen years imprisonment and a fine of a maximum of one hundred million rupiah (Kementerian Hukum dan Hak Asasi Manusia Republik Indonesia, 2009)

On that basis, it is clear that the public is also responsible for maintaining the safety and securityof aviation. This is one of the reasons for the fulfillment of the safety requirements in the use of airspace, as referred to in article 1 above.In this case study, there are four examples of cases related to the misunderstanding by aircraft passengers of their actions that threaten the safety and securityof aviation.

The first case occurred on September 30, 2013, when the aircraft with flight number JT 775 from Manado to Jakarta, is preparing to taxi. Suddenly a passenger opened the emergency exit door. This action was driven by a delayed flight for almost 1 hour. The air conditioner (AC) inside the cabin did not working properly, and made the temperature in the cabin increased. The passengers then protested to the flight attendant and the pilot to ask to get off the plane, but there were no responses. In such a panicked condition, 
the pilot pushed back the aircraft to the taxi position, but it occurred that the passengers opened the emergency exit (Michel Karundeng, 2013).

The second case occurred in Ngada District, East Nusa Tenggara Province (NTT), on Saturday 21 December 2013, when the Regent of Ngada was about to fly from Kupang to Turelelo-Soa Airport in Bajawa (capital of Ngada regency). The problem was trivial, a day before the departure date (Friday, December 20, 2013), the airline (Merpati) has sold the tickets to Bajawa out, so the Regent did not get a ticket to Bajawa. However, on Friday afternoon Merpati reported there was one available ticket which could be used by the Regent, as there were passengers canceling their flight. The Regent then purchased the tickets. On the day of departure, prior to departure time, in accordance with international flight procedures, Kupang airport three times announcing boarding callsfor the Regent. Until the departure time, the Regent was not in the boarding room, and it was decided that the plane should be departed without having the Regent on board. When the plane had taken off, the Regent asked The Municipal Policeto block Turelelo-Soa Airport in Bajawa. As a result, Merpati aircraft from Kupang could not land since the runway was blocked byThe Municipal Police. The plane eventually returned to Kupang. Not long afterwards the Regent landed by TransNusa aircraft at Turelelo-Soa-Bajawa Airport (Daniel HT, 2015).

The third case, a young man with the initial MSA (19), on April 7, 2015, recklessly hiding in the wheel well of Boeing 737-800 flight number GA-177 with destination to Soekarno-Hatta International Airport.Without being known by the apron officer of Sultan Syarif Kasim Airport II Pekanbaru, he managed to enter the airport area, after climbing the airport fence. (Denny Irawan, Bakti Munir, Muh Shamil, 2015)

The fourth case, a university lecturer in Makassar, with the initial Dr HI (51), a passenger of Garuda Indonesia flight GA 611 from Makassar to Jakarta, was dropped off from the plane due to saying the following words: "Be careful, it has valuable items in it, but not a bomb". His words was delivered when aflight attendant put in the lecturer's luggage into the cabin 
baggage compartment. Hearing the word "bomb", the flight attendant immediately reported it to the pilot who then reported it to Garuda Indonesia security officer. This was occurred on March 3, 2017. (Padmasari, 2017).Still at the same airport, with the initial CW, a first police officer with Superintendent Two rating, also said that he had a bomb in his luggage bag (Cipto, 2016).It was not only once passengerssaying that they carry a bomb in their luggage. Based on the data from the Ministry of Transportation, during 2015, there were six cases of aircraft passengersdelivering false information claiming that they carried a bomb (Putera, 2015).

On the basis of such cases, researcher will conduct a study on passenger motives in doing several actions that could threaten the safety and security of aviation. This study is important, considering that in the last five years, as has been pointed out earlier, there are still many other cases where passengers of airplanes have the potential to become a threat to the safety and security of flight.

\section{Method}

This research is a descriptive qualitative research with case study approach (case study). Case study is a study that focuses intensively on a particular object that studies it as a case. In this research the object is the motive of airplane passengers that can threaten flightsafety and security. Data were collected from various sources such as from the law and news in mass media. To test the validity of the data and find the objective truth, the researcher did triangulation. Of the four models of triangulation proposed by Denzin (methods, investigators, sources and theories) (Yeasmin \& Rahman.K.F, 2012)researchers used triangulation of data sources. Triangulation of data sources is done by seeking the truth of information through various data sources. From the various data the researcher can have a deep understanding of the observed objects. 


\section{Discussion and Result}

In psychology, motives are defined as the impulses that could make a person or group of people act or behave to achieve the desired goal. That is, an action is preceded by a motive to conduct such actions or deeds and there is a goal to be achieved. As such, the person will set a plan of what should be achieved from their actions to avoid any failure. Thus, the motive is closely related to the plan, as well as awareness, on why an action or deed should be done.

In the world of aviation, a case example corresponds to the above definition was done by Francisco Paula Gonzales (27 years). Gonzales is in a state of depression due to his marital and financial problems. Almost half of his income was used to pay various loans or debts. One day he planned to travel to San Francisco. The day before he headed to San Francisco, Gonzales bought a $\$ 105,000$ life insurance in the name of his wife. He also bought a Smith \& Wesson Model 27 revolver with the S201645 serial number. The night before leaving, he gambled in the casino. He doesn't even count how much he lost his money that night. On May 6, 1964 he departed from Reno, Nevada to San Francisco on board the Pacific Air Lines F-27 flight 773. In that flight Gonzalez shot Capt. Ernest Clark (52) and co-pilot Ray Andress (31), resulting in the plane crash. (Civil Aeronautics Board Aircraft Accident Report, 1964).

In this case, the main motive was insurance claims. Action committed suicide by shooting the pilot and copilot showed the passengers have the potential to threaten the safety and security of aviation.

Sometimes, an action is done in a sudden, without any underlying motive and plans. Even when there is a motive, it is solely because of certain circumstances that force the action to be done, not because there are motives and plans that underlying it.

In the first case, the passenger's actions of opening the emergency exit is not started with a motive and plan to threaten the flight safety and security. From the side of the perpetrators, the act of opening the emergency 
exit is considered as an attempt to survive from the hot temperature inside the cabin, passengers were worried that they wouldbe lack of oxygen.

According to Reza Indragiri Amriel, a Forensic Psychology Expert from the University of Indonesia, the passenger's motive of carrying out such actions begins with situational factors that can trigger passengers into uncontrolled actions in search of their own satisfactionin terms of passenger rights. For example, delayed departure schedules, long queues, passenger's bustlingwhen they prepare to occupy their seats, as well as overheating due to the cabin chillers have not been activated yet(Amriel, 2013).Previously, Bielen and Demoulin (2007), explained that delays in flight schedules can affect passenger perceptions of their satisfaction with airline services and can cause negative intentions and behavior. Meanwhile Casado Diaz and Mas Ruíz (2002) explain that no passengers who want to wait for flight delaysfor a long time. Passenger'sdissatisfaction can lead them to act or behave negatively (Taylor, 1994; Tom and Lucey, 1995; Van Vaerenbergh et al., 2014). When there is a delay for a long time, and the airline does not proactively manage passenger complaints, passengers will then express their negative emotions.(Kim \& Park, 2016)

Even with cabin overheating reason, the passenger's act of opening the emergency door remains unjustifiable, because this is considered as a violation to the Article 54 of the Flight Acts,where passengers are prohibited to: take any action that could harm the safety and security of aviation, including violation of the order, taking or destructing any aircraft equipments, immoral conduct, disturbing tranquility, and operating electronic equipment that may interfere with flight navigation. (Kementerian Hukum dan Hak Asasi Manusia Republik Indonesia, 2009).

If we take a deeper review to these cases, passenger action of opening the emergency exit is not solely the passenger fault, but also the fault of flight personnel, both the crew on board (pilot and FA), as well as unresponsive and sensitive (unresponsive) technicians against failure of the cabin cooling system, because after the incident, the company admitted that there was a damage to the cabin cooling and they did not respond quickly to 
passenger complaints. Indeed, in the Civil Aviation Safety Regulation (CASR) Part 121 Certification And Operating Requirements: Domestic, Flag, And Supplemental Air Carriers, Subpart R - Cabin Safety article 121.501, Compliance with Briefings or Safety Instructions and Carriage of Weapons clause (a), whoever is on board an aircraft must obey crew instructions about the safety and security of the flight. (Kementerian Perhubungan Republik Indonesia, 2008)

The question is whether the passengers - especially the ones sitting near the emergency exits - understand the safety briefings and instructions provided by the flight attendants. Based on experience, the flight attendantssimply explained that, those sitting near the emergency exits are adults and not women. Even if women are allowed, then the woman is considered to be able to overcome the emergency situations. In fact, in the Aviation Act article 56 paragraph (1) it is explained that, passengers who are unable to carry out emergency actions during flight are not allowed to be seated at the emergency exit of the aircraft.(Kementerian Hukum dan Hak Asasi Manusia Republik Indonesia, 2009).

Certainly the definition of being incapable as mentioned in the clause is not merely incapable in terms of physical ability to open an emergency door, but also incapable in terms of following instructions and have a selfcontrol in case of emergency situations. This incident proves that, not all passengers who occupy theemergency exit seat, are people who meet the requirement as stipulated in the Aviation Act, as well as having a comprehensive understandingto the rules of safety and security.

Unlike the first case, in the second and third cases, the perpetrator's motive to perform a dangerous action has previously been planned. Blocking the airport by the perpetrator is obviously already been planned. The perpetrator has purchased the Merpati airfare, but then he did not use it. Instead, he chartered a private jet. The principal motive for blocking the runway is because the Regent wants to show his power. This particular case shows that, the motive of an action could arise when someone who has power but is not respected, will havea tendency to show his power, even if 
he is in the wrong position. It also shows that, as the highest officials in the region, the Regentare not familiar with the rules of aviation safety and security. In accordance with article 210 of the Aviation Act, it is stated that other than those who are granted permission by the airport authorities, no person is allowed to be in certain areas of the airport which may allows him to create any obstacles, that could endanger the safety and security of aviation. Criminal sanctions that can be imposed on the perpetrator is a maximum of one year being arrested in jail or a maximum fine of one hundred million rupiah. The airport authority is the one that allowed to take any action in the airport area. Article 210 is reinforced by article 228 on the duties and responsibilities of the Airport Authority that is to ensure the safety, security, smoothness, and comfort at the airport and ensure the implementation and fulfillment of flight safety and security requirements, including resolving problems that may disrupt the smoothness of airport operation activities that could not be resolved by any other agencies, and article 229, that airport authority also has several responsibilitiesranging from regulating, controlling and overseeing the implementation of security and safety as well as the convenience at the airport including the use of aviation operational safety areas and the working area of airports.(Kementerian Hukum dan Hak Asasi Manusia Republik Indonesia, 2009)

This case also shows the Regent's incomprehension of the safety and security risks of blocking an aircraft for landing, in relation to the fuel supply. Fortunately, the aircraft can return to Kupang with the remaining fuel available.

The same thing happened in the third case, where both cases shows incomprehension of the risks that will occur to the perpetrator of the actions he did. According to Health Colonel Dr dr Wawan Mulyawan, SpBS (K), SpKp, aviation medical specialist from Lakespra "Dr Saryanto" Jakarta, (Lakespra is Indonesian Air Force Aviation and Space Health Institute), 1 hour and 10 minutes of flight from Pekanbaru to Jakarta with 0 degree air temperature and without any safety equipment, is dangerous for health. At 0 
degree Celsius, human body will freeze. It can be imagined how is it going at an altitude of more than 25 thousand feet with outside air temperature can reach -40 to -60 degrees Celsius. The higher the altitude, the air pressure is much lower compared to the pressure on the surface level, so it is very likely the perpetrator experienced decompression sickness, and moreover could also causing death. Decompression sickness is a medical condition that occurs when the accumulation of dissolved nitrogen forms air bubbles that clog the bloodstream and the nervous system (Merry Wahyuningsih, 2015).

The perpetrators' motive to get into the wheelwellof the aircraft simply because of an excessive desire to go to Jakarta and meet the President, but by ignoring the security and self-safety, is clearly irrational. The similarity with the second case lies in terms ofperpetrator's insufficient knowledge and understanding of aviation safety and security.

There are three things that can be inferred from these cases. First, if a person has a motive to fulfill his own desire, then that person will take any action, even if it is irrational and dangerous for theirselves. Second, even if a person has a huge desire to commit into actions or acts that threaten and endanger the safety and security of himself or others, but there is no room for that person to do so, such act will not happen. As an example, a person who intends to commit to do evil deeds, and that intention has already known by the others, then his movements are observed at all times and he is advised about the consequences that will occur following his action, then such act could be prevented. Third, the motive for carrying out the desire can appear in a person not solely because of his own willingness, instead there are certain situations and conditions that provide space to the person to carry out their motive. In this case, negligence of airport officers and security, such as damaged fences, provides an opportunity for the perpetrator to execute his motives.

In relation to this case, the Officer In Charge (OIC) unit, commonly known as the Airport Duty Manager, is responsible for solving any problems at the airport, from airport operational issues related to PT AP II, 
Airlines, Ground handling or any other matters related to other agencies such as Immigration, Customs, Quarantine and others, but not limited to any public or passengers.(Resky \& Simarmata, 2014)

In the fourth case, there is something to be aware of, that the offender is a highly educated person (lecturer) and the other one is a police officer, who should know and understand well that such actions are wrong. The question is, why an educated person, who knows and understands the risks that will arise from his actions, did such wrong action.

In conclusion, even a highly educated person may commit an action that endanger the safety and security of aviation, without any motive, other than for teasing purposes. By common sense, it is impossible for the perpetrator to commit a crime, let alone conducting an act of terror, by first notifying the other person who is not concerned with his crime. Moreover, many passengers already know the same cases occurred in previous years. However, vigilance to aviation safety and security should not be ignored.

According to the article 344 item e of Aviation Act, everyone is prohibited from delivering false information that endanger the safety of aviation and air transport, and is considered to be a violation of the law. The sanctions as stipulated in article 437, are one year sentenced, or eight years in the event of an accident or loss of property and 15 years of imprisonment in the event of causing death.(Kementerian Hukum dan Hak Asasi Manusia Republik Indonesia, 2009)

Several cases that can threaten flight safety and safety are not limited to happen in Indonesia only. According to IATA, sourced from airlines around the world, unruly passenger behavior is increasing rapidly. By 2015 there were 10,854 unruly passenger incidents or an increase of about 17 percent from the previous year or about 30 cases per day. Chris Goater, an IATA spokesperson, describes unmanageable forms of passenger behavior, among others are: verbal abuse, not following flight crew instruction and other forms of anti-social behavior. Another 11 percent were involved in physical squabbling and causing aircraft damage. Nearly a quarter of these cases are identified for alcohol or drug consumption(Mccartney, 2016). 
Reza also agreed that alcohol consumption and mental disorders are the dominant cause of passengers taking actions that could endanger the flight. In different cases, Reza explains the need for medical examination of passengers'unruly behavior, to check the substances inside the offender's body, such as alcohol. Similarly, psychological examination should also be conducted to identify the conditions associated with the temperamental behavior while on the plane. (Amriel, 2013).

A study conducted in September towards 750 adults in the United States with an average age of 40 years, as published in the Social Science Journal, found that unruly passenger behavior was mostly done by men and more due to lack of self-control. According to Dr. Ryan Meldrum of Florida International University, some unruly passenger behavior has resulted in emergency landing or diverting to other airport, which is certainly dangerous for flight safety and security. For such incidents, IATA encourages countries around the world to renew their aviation laws, and asks to incorporate a clause stating that airlines may seek a compensation from passengers for their actions that may result in the airline company loss. In the United States, by severely penalizing passengers who commit acts that endanger the safety of aviation, have effectivelyreduce the number of unruly passenger cases. Data from the Federal Aviation Administration (FAA) shows from 1997 to 2004, there are more than 200 cases of mischievous passengers in the US. The peak occurred in 2004 with 310 cases. As of October 2016, there were only 60 cases. It is estimated that by the end of the year there will be fewer than 80 cases (Mccartney, 2016).

Reza also agreed on the imposition of sanctions on unruly passengers so that Indonesian airlines are not subject to sanctions as experienced by Europeanairlines whoface public lawsuitscausing them to pay $\$ 32,000$ for not forcing passengers to switch off their mobile phones for the purpose of flight safety.(Amriel, 2013) 


\section{Conclusion}

First, out of four cases studied, although there is no specific motive was found, like whatwas done by Gonzalez or terror intention, what the perpetrators did in the four cases discussed in this study were threats for the safety and security of aviation in Indonesia. Passengers or prospective passengers become concerned about their safety and security when using air transport services. The greater impact of such passengers' actions is the decline of Indonesia's aviation reputation in the eyes of the world, as stakeholders consider Indonesian aviation to be incapable of enforcing regulations, whether the one issued by ICAO or the Indonesian law, including the airline's aviation safety and security manual.

Secondly, the offender's acts that could jeopardize the safety and security of the flight may not be based on the motive for harming himself or others, but such act is done because of urgent situations, personal ego, risk ignorance and false deeds, but there is one important thing, that is the limited knowledge and understanding of passengers on the legislation, particularly those related to the safety and security of aviation. Limitations of knowledge and understanding can cause passengers to take action that could threaten the safety and security of aviation. From these cases, it can be concluded that not all passengers know and understand the laws and regulations relating to aviation safety and security, including those who are respectable and well educated, except for the perpetrator in thethird case. If those who hold the power and highly educated violate the legislation of law, let alone the layman.

Third, passengers are very likely to take action that could threaten the safetyand security of the flight, all of a sudden, without any planned motive, but because it is triggered by a sudden situation. This is what the aviation personnel on duty,both on board the plane and on the ground, need to be aware of.

To prevent the occurrence of actions that could threaten the safety and security of aviation, such as those four cases, there are three things that need to be done. First, the Government and airlines need to continually socialize 
the rules of aviation safety and security through various media, in order to foster community careness and awareness, especially passengers of airplanes against things that can threaten the safety and security of aviation. Second, airlines and airport operators need to improve their personnel capabilities in communications and human relations, with the purpose to be able to treat passengers properly and humanely. Third, regulators need to take strict supervision of airlines, especially companies that are often delayed, so that trivial issues that can pose a security threat and flight safety can be prevented.

In addition to the above, according to Chapter XIX article 381 to 393 of the Civil Aviation Act of 2009 regarding aviation human resources, the government is responsible for preparing and developing human resources in the aviation field. Aims and objectives of aviation human resources are professional, competent, disciplined, reliable and having integrity. It shall consist of aircraft personnel, air transportation personnel, airport management, light air navigation, aviation safety and aviation security. In order to achieve the aims and objectives, the MOC stipulates policies on preparation and development of human resources in aviation fields covering manpower planning, education and training, expansion of job opportunities and supervision, monitoring and evaluation. (Martono \& Marina, n.d.)

\section{References}

Amriel, R. I. (2013). Memahami psikologi dunia penerbangan. Koran SINDO. Retrieved from https://nasional.sindonews.com/read/750098/18/memahamipsikologi-dunia-penerbangan-1371267585/13\%0A

Cipto, H. (2016, January). Penumpang yang Bercanda Bawa Bom di Bandara Makassar adalah Perwira Polda Bali. Retrieved from http://regional.kompas.com/read/2016/01/10/18494401/Penumpang.yang.Ber canda.Bawa.Bom.di.Bandara.Makassar.adalah.Perwira.Polda.Bali\%0A

Civil Aeronautics Board Aircraft Accident Report. (1964). Crash - 1964 May 07. Retrieved from http://www.pacificairlinesportfolio.com/crash-1964-may-07

Daniel HT. (2015). Tuntut Bupati Itu Secara Perdata dan Pidana! Retrieved from https://www.kompasiana.com/danielht/tuntut-bupati-itu-secara-perdata-danpidana_55203a02a333119744b65abb\%0A\%0A23

Denny Irawan, Bakti Munir, Muh Shamil, A. C. (2015). Penumpang Gelap Masuk Roda

$$
\text { Pesawat. }
$$


https://nasional.sindonews.com/read/986484/149/penumpang-gelap-masukroda-pesawat-1428459983

Kementerian Hukum dan Hak Asasi Manusia Republik Indonesia. (2009). UndangUndang Nomor 1 Tahun 2009 Tentang Penerbangan. https://doi.org/10.1017/CBO9781107415324.004

Kementerian Perhubungan Republik Indonesia. (2008). CIVIL AVIATION SAFETY REGULATION (CASR) PART 121 CERTIFICATION AND OPERATING REQUIREMENTS: DOMESTIC, FLAG, AND SUPPLEMENTAL AIR CARRIERS.

Kim, N. Y., \& Park, J. W. (2016). A study on the impact of airline service delays on emotional reactions and customer behavior. Journal of Air Transport Management, 57, 19-25. https://doi.org/10.1016/j.jairtraman.2016.07.005

Martono, K., \& Marina, S. (n.d.). Domestic Air Transport Regulations in Indonesia. Jurnal Manajemen Transportasi \& Logistik (JMTranslog) - Vol. 03 No. 1, Maret 2016, 3(1), 1-19.

Mccartney, S. (2016). Bad flight behaviour is on the rise, 10-12. Retrieved from http://www.theaustralian.com.au/business/wall-street-journal/bad-flightbehaviour-is-on-the-rise/news-story/2dce3dedba7271171040a3cb25e966c4

Merry Wahyuningsih, C. I. (2015, April). Yang Terjadi Pada Tubuh Saat Terbang. CNN Indonesia. Retrieved from https://www.cnnindonesia.com/gayahidup/20150408114756-255-45010/yang-terjadi-pada-tubuh-saat-terbangmenyusup-di-roda-pesawat/\%0A

Michel Karundeng. (2013). Seluruh Penumpang Lion Air Berdiri Saat Lepas Landas. http://www.tribunnews.com/regional/2013/09/30/pesawat-lion-air-dimanado-sempat-take-off-dengan-seluruh-penumpang-berdiri

Padmasari, S. I. (2017, March). Candaan bom di Bandara Makassar , Garuda Indonesia delay enam jam. Retrieved from https://www.merdeka.com/peristiwa/candaan-bom-di-bandara-makassargaruda-indonesia-delay-enam-jam.html\%0A

Putera, A. D. (2015). Ada Enam Kasus Penumpang Pesawat Bercanda Bawa Bom Sepanjang 2015, pp. 29-30. Retrieved from http://megapolitan.kompas.com/read/2015/12/15/20244151/Ada.Enam.Kasus. Penumpang.Pesawat.Bercanda.Bawa.Bom.Sepanjang.2015\%0A

Resky, M., \& Simarmata, J. (2014). FUNGSI dan KELEMAHAN UNIT OPERASI PELAYANAN DI BANDARA. Jurnal Manajemen Bisnis Transportasi Dan Logistik, Vol.1.No1 September 2014, I(September), 1-8.

Yeasmin, S., \& Rahman.K.F. (2012). "Triangulation" Research Method as the Tool of Social Science Research. Bup Journal, 1(1), 154-163. Retrieved from http://www.bup.edu.bd/journal/154-163.pdf 